\title{
Differentiation pattern in the use of space by males and females of two species of small mammals (Peromyscus difficilis and $P$. melanotis) in a temperate forest
}

\author{
Ivan Mijall De-la-Cruz ${ }^{*}$, Alondra Castro-Campillo', Alejandro Zavala-Hurtado', Arturo Salame-Méndez² and José Ramírez-Pulido \\ ${ }^{1}$ Department of Biology, Metropolitan Autonomous University, Iztapalapa Unit (UAM-I). Av. San Rafael Atlixco 186, CP. 09340, \\ Ciudad de México, México.Email: imda@xanum.uam.mx (IMDC)*, acc@xanum.uam.mx (ACC), jazh@xanum.uam.mx (AZH), jrp@ \\ xanum.uam.mx (JRP). \\ ${ }^{2}$ Department of Reproduction Biology, Metropolitan Autonomous University, Iztapalapa Unit (UAM-I). Av. San Rafael Atlixco 186, \\ CP. 09340, Ciudad de México, México. Email: asam@xanum.uam.mx (ASM) \\ * Corresponding author
}

The distribution patterns of individuals together with mechanisms that maintain them have significant implications for population-level processes. Sex-specific differences in home-range may strongly influence the spatial distribution of individuals, while the differential use of space by the sexes can yield insights into the mating system and the life history of the species. Sexual differences in the use of space could be due to different habitat requirements during the breeding season. This is interesting because the males and females likely are interacting with operational sex ratios and mating strategies. Here, we evaluated for ten months of the year 2014, the spatial patterns of ecological distribution in males and females of two species of deer mice (Peromyscus difficilis and P. melanotis) that coexist in a temperate forest. Also, we assessed the variation in the use of space by males and females in both Peromyscus species and we analyze the intensity of positive association or repulsion between males and females. During drought and rain seasons, males and females of both Peromyscus were captured. The sex and reproductive status of each were identified. To analyze the spatial patterns of ecological distribution, we used the Nearest Neighbor Analysis. Kernel spatial analysis was performed to evaluate the variation in the use of space of males and females between seasons. The Ripley's K bivariate function was carried out to assess the positive association or repulsion between males and females in each season. We found a different use of space between sexes. Our evidence shed light on the respective life histories of these species and provides information on possible factors that they may be using to coexist successfully among them. We conclude that in this temperate coniferous forest: 1 ) use of space by $P$. difficilis and $P$. melanotis, is influenced by both sex and by the reproductive season, and that this pattern varies, according to shifts on ecological conditions that promote variation and availability of resources during the two pluvial seasons; 2 ) there are interspecific differences in the use of space with conspicuous intraspecific differences in females and males of $P$. difficilis (e. g., males are more territorial, and both sexes only become more clustered during the breeding season), while both sexes of $P$. melanotis are more gregarious; and 3 ) there is a clear differentiation in the reproductive seasons of both species that could be related to resources availability, such as shelters and food.

Los patrones de distribución de los individuos junto con los mecanismos que los mantienen, tienen implicaciones significativas en los procesos que ocurren a nivel poblacional. Las diferencias sexo-especificas en el ámbito hogareño pueden influenciar fuertemente la distribución espacial de los individuos, mientras que el uso diferencial del espacio por los sexos puede ayudar a comprender los sistemas de apareamiento y la historia de vida de las especies. Las diferencias sexuales en el uso del espacio por las especies podría deberse a los distintos requerimientos de hábitat que tienen los individuos durante su época reproductiva, esto es especialmente interesante por que los machos y las hembras probablemente están interactuando con proporciones de sexo operacionales y distintas estrategias de apareamiento. Aquí, evaluamos durante diez meses del año 2014, los patrones espaciales de distribución ecológica en los machos y las hembras de dos especies de "ratones ciervos" (Peromyscus difficilis y P. melanotis) que coexisten en un bosque templado. También, evaluamos la variación en el uso del espacio por parte de ambos sexos en las dos especies de Peromyscus y analizamos la intensidad de asociación positiva o repulsión entre los machos y las hembras. Durante las épocas de secas y lluvias del año 2014, capturamos a individuos machos y hembras de ambos Peromyscus así como identificamos el estado reproductivo de cada individuo. Para analizar los patrones espaciales de distribución ecológica, usamos el "análisis del vecino más cercano". El análisis espacial de Kernels fue utilizado para evaluar la variación en el uso del espacio de machos y hembras entre épocas. Mientras que la función bivariada $\mathrm{K}$ de Ripley fue usada para evaluar la asociación positiva o repulsión entre machos y hembras en cada época. Los resultados demostraron el uso distintivo del espacio entre los sexos, y mostraron evidencia sobre las respectivas historias de vida de estas especies y brindan información sobre posibles factores que pueden estar usando para convivir exitosamente entre ellas. Concluimos que en este bosque templado de coníferas: 1) el uso del espacio por $P$. difficilis y $P$. melanotis, está influenciado por el sexo de los individuos y por las épocas reproductivas de cada especie, estos patrones varían de acuerdo a los cambios que ocurren en las condiciones ecológicas (i.e., variación en la disponibilidad de recursos) durante las dos épocas (secas y lluvias), 2) hay diferencias interespecíficas así como diferencias intraespecíficas visibles en el uso del espacio entre las hembras y los machos de $P$. difficilis (e. g., los machos son más territoriales y ambos sexos solo se agrupan más durante la temporada de reproducción), mientras que ambos sexos de P. melanotis se comportan de manera más gregaria, y finalmente, 3) hay una clara diferenciación en las épocas reproductivas de ambas especies que podría estar relacionada con la disponibilidad de recursos, como refugios y alimentos.

Keywords: ecological distribution; Peromyscus; spatial analysis; small mammals; use of space.

๑ 2019 Asociación Mexicana de Mastozoología, www.mastozoologiamexicana.org 


\section{Introduction}

Spacing patterns of individuals together with mechanisms that maintain them have significant implications for population-level processes (Adler 2011). For instance, sex-specific differences in home-range may strongly influence the spatial distribution of individuals (Blondel et al. 2009), while differential use of space by the sexes can yield insights into the mating system, thus improving our comprehension of little-studied species (Ostfeld et al. 1985; Gaulin and Fitzgerald 1988; reviewed in Clutton-Brock 1989, 1991; Heske and Ostfeld 1990). Indeed, rodents exhibit intra-sexual differences in home range sizes and spacing patterns, since male home-ranges are more extensive than those of females (Bowers and Smith 1979; Morris 1984; Kamler and Gipson 2003; Blondel et al. 2009). Also, spatial partitioning between the sexes (Morris 1984) may result from competitive interactions for habitat-based resources in short supply, such as foraging areas or refuge cover, or from intrinsic differences on reproduction roles (e. g., females select a dense cover for natal care). Although males and females must cooperate for sexual reproduction, their best reproductive strategies to maximize fitness, frequently conflict with one another (Parker 1979; Arnqvist and Rowe 2005; Morris and MacEachern 2010). These differences between the sexes in habitat requirements are especially interesting because they are likely to interact with operational sex ratios and mating strategies (Morris and MacEachern 2010).

The space partition by sexes can become very complex when they have to coexist or compete with their counterparts in another congeneric species, especially if habitat heterogeneity also varies spatiotemporally (De-la-Cruz et al. 2018). For instance, temporal fluctuations can stabilize coexistence via storage effect (Chesson 2000), when interannual variation in climate or resource availability favors alternatively one group of species over the others (Zavaleta et al. 2003). Therefore, in order to document how sexual partition of space is influenced by breeding season and by the presence of another congeneric species, here we studied the differential use of space by males and females of two species of deer mice (Peromyscus difficilis and P. melanotis) in two seasons (drought and rain) in a temperate coniferous forest in Central Mexico. Hence, our four objectives were: 1) to analyze capture variation in males and females for both species; 2 ) to identify spatial patterns of ecological distribution (dispersion) of each sex for both species; 3 ) to assess variation in the use of space by males and females in each species, and 4) to analyze the intensity of association or repulsion within and between the sexes in the two species.

\section{Methods}

Study system. Our biological models were two syntopic species of Peromyscus in a temperate mountain forest in Central Mexico. Peromyscus difficilis (J. A. Allen, 1891) is an endemic species with scansorial to semiarboreal locomotion, which dwells in a wide variety of habitats, from dry and semiarid hills to montane forests (Fernández et al. 2010). P. difficilis is consider a medium-sized mouse (total length 180 to 260 $\mathrm{mm}$ ) with a long tail (91.0 to $145.0 \mathrm{~mm}$ ). Peromyscus melanotis (J. A. Allen and Chapman 1897), is a mostly grounddwelling (cursorial), quasi-endemic species, whose range overlaps extensively with the former deer mouse (ÁlvarezCastañeda 2005). P. melanotis is considered a small size mouse (total length 140 to $177 \mathrm{~mm}$ ) with a small tail (49 to $75 \mathrm{~mm}$ ). In the Transmexican Neovolcanic Belt, P. melanotis is restricted to the mountainous highlands with pine-fir forests (Álvarez-Castañeda 2005) and mixed forests of coniferous and broad-leaved trees (Carleton 1989).

Study area. We worked in a temperate forest (conifers and broad-leaved trees) at the National Park Desierto de Los Leones (PNDL; CONANP 2006), Mexico City, within the Transmexican Neovolcanic Range. Temperature averages $12.6 \pm 6{ }^{\circ} \mathrm{C}$ from April to July, while it descends to $8.1 \pm 2{ }^{\circ} \mathrm{C}$ from December to February. Rainfalls occur from late spring throughout summer (May to August), with average precipitation of $235 \pm 30 \mathrm{~mm}$, though this period can go until mid-fall (October). From winter to early spring (December to March), precipitation average becomes $12 \pm 4 \mathrm{~mm}$, introducing dry and cold weather (CONANP 2006). Dominating vegetation by strata includes: canopy, Abies religiosa, Pinus hartwegii, P. leiophylla, P. montezumae, Prunus serotina, Garrya laurifolia, Salix paradoxa, and Buddleia cordata; understory shrubs, Baccharis conferta and Senecio spp., and understory herbs, Acaena elongata, Sigesbeckia jorullensis, and Alchemilla procumbens; ground level, a rich variety of mosses and fungi (CONANP 2006).

Mice sampling design. We captured mice along ten months to include either dry season (October 2013 to February 2014) and rain season (March 2014 to July 2014), within a $2,475 \mathrm{~m}^{2}$ surface plot at an altitude of $2,289 \mathrm{~m}$. The plot was configured as a grid ( 12 vertical lines, A - L; 10 horizontal lines, 1 - 10) marking intersections each $5 \mathrm{~m}$ with buried wood stakes $(150 \times 2.5 \times 2.5 \mathrm{~cm})$ to construct a coordinate system for independent sampling stations, where we set 120 Sherman live traps (Tallahassee, FL 32303, USA), baited with oat flakes and vanilla scent (Ramírez et al. 1989). Each independent sampling station was considered as a replicate of each other. Therefore, each month, we set traps for two continues nights (in total we carried out 20 capture events resulting in 2,400 trap-nights), shortly before dusk, left open overnight, and checked at next day dawn. To avoid bias in the abundance and use of space of both Peromyscus during each sampling session, we used a temporal mark (gentian violet applied in the abdomen of the mice) to identify the captures and recaptures. If we saw signals that the gentian violet was disappearing in the abdomen of the mice, we applied it again. This temporal mark enabled us to count the net frequency of the individuals in each microhabitat. We carried out an initial analysis with the recaptures, and we found the same patterns that we obtained with the first frequency (without recaptures). Thus, for the analyses, we used only the first capture data for each of the 120 sampling stations during all trapping sessions. All the 
traps were cleaned, and bedding was changed at each trap check event (Brouard et al. 2015). Also, to avoid bias in the frequency quantification due to recurrence behavior or shyness of the mice to the trapping, in all capture sessions the traps were moved within an influence zone of $2.5 \mathrm{~m}^{2}$ that was assigned to each sampling station (Brouard et al. 2015). Coordinates of all trapped mice were recorded, and the species and sex, and reproductive activity determined through visual inspection.

Statistical analysis. To map variations in point density captures of small mammals, and to find density gradients across the plot area, we used the Kernel function. To test for type of ecological dispersion patterns (i. e., clustering or overdispersion) for males and females of both species within the plot, at each season, we used a"Nearest Neighbor Analysis" (Clark and Evans 1954), applying the wrap-around edge effect adjustment, which is only appropriate for rectangular domains, as our plot. In general, the "Nearest Neighbor Analysis" compares the mean distance of each from its nearest conspecific neighbor with the mean distance expected for a set of points randomly dispersed at the same density (Vázquez and Álvarez-Castañeda 2011). The ratio of the observed mean distance to the expected distance $(R)$ indicates how the observed distribution deviates from random. Clustered points give $R<1$, Poisson patterns give $R \sim 1$, while overdispersed points give $R>1$. We performed these analyses in PAST software (ver. 3.14, Hammer et al. 2001).

To assess whether the sexes were associated or disassociated within and between species, we compared its dispersion patterns using Ripley's K bivariate function (Ripley 1977), since the method considers all distances among individuals located under a Cartesian scheme $(X, Y)$ in a quadrat plot (Ripley 1977; Dale 1999; Zavala-Hurtado et al. 2000). We used PASSaGE (ver. 2, Rosenberg and Anderson 2011) to carry out Ripley's bivariate K analysis. We used the option to test the associations conditional on current locations hypothesis in PASSaGE. In this test, the point locations remain fixed, and only the types are randomized (the sexes). The number of each type remains fixed, but the association of each type with a specific, fixed location is randomized. In this case, one is not testing whether the points are themselves random or clustered, but rather whether the association of type A with type B (males vs. females) is what one would expect given the locations of the points as fixed (Rosenberg and Anderson 2011). We assigned coordinates to each sampling stations considering $5 \mathrm{~m}$ distance between them. Therefore, because each sampling station had a Cartesian coordinate system, we used as data input for each station where we capture mice. Thereby, our null hypothesis involved independence between females and males (Ripley 1977; Dale 1999), since we were interested in whether points of a specific type (e. g., females) were associated, or disassociated, with points of the other specific type (e. g., males). In other words, Ripley's $\mathrm{K}_{12}(d)$ allowed us to assess spatial attraction or repulsion between the sexes within and between species, among the stations of the plot. To evaluate the statistical significance of $\mathrm{K}_{12}(d)$, we estimated $95 \%$ confidence envelops $(95 \% \mathrm{Cl})$, using a Monte Carlo procedure, based on 1000 stochastic relocation simulations of the sampling stations in the plot (Upton and Fingleton 1985; Zavala-Hurtado et al. 2000). When $L(d)$ was positive and took values over the upper limit of the confidence region, we inferred dissociation or repulsion between the sexes at the corresponding (d) scale; whereas a significant negative deviation indicated us a pattern of association or attraction between the two sexes (Dale 1999). If $L(d)$ remains within the limits of the 95 $\% \mathrm{Cl}$ for a given value of $d$, the null hypothesis of independence between the two contrasts cannot be rejected (Dale 1999). The height of the $L(d)$ function (peak height) indicates the intensity of the association or repulsion. Control for edge effect was carried out for the analysis by rescaling the count based overlap with the study boundary (Rosenberg and Anderson 2011).

\section{Results}

In this study with a capture effort of 2,400 traps-nights, we captured 110 individuals from both species during the dry season, while for the rainy season we captured 168 individuals. In the dry season, we captured 64 individuals of $P$. difficilis. While for P. melanotis during the dry season, we captured 46 individuals. In contrast, during the rainy season, the frequency of capture of $P$. difficilis was 87 individuals. While the total captures in this season for $P$. melanotis were 81 individuals. We also captured along the study 16 individuals of Sorex saussurei, two Neotomodon alstoni, five individuals of Reithrodontomys chrysopsis and two individuals of Cryptotis alticola. In the dry season (Table 1), the number of adult males was higher than that of females in both species ( $P$. difficilis, 47:17; $P$. melanotis, 29:17, respectively), and overall, $P$. difficilis was more abundant than $P$. melanotis. Nonetheless, the number of reproductive males to females was very similar in both species within both seasons (Table 1: P. difficilis, 14:13; P. melanotis, 9:7). In the rainy season (Table 1), the number of captured adult males was higher than that of adult females in P. difficilis (60:27), while this ratio was very similar between the sexes in $P$. melanotis (42:39). Although we documented a significant increase in captures of $P$. melanotis, $P$. difficilis remained as the more abundant species in the rainy season (Table 1 ).

Table 1. Capture variation for the sexes and reproductive individuals in two syntopic species of Peromyscus, along two seasons in a temperate forest. Note that there were more captured males than females in both species, more reproductive individuals of $P$. difficilis during the dry season, and more reproductive individuals in $P$. melanotis during the wet season. The values of reproductive individuals belong to the total males and females captured during each season.

\begin{tabular}{lrrrr}
\hline & \multicolumn{2}{c}{ Dry } & \multicolumn{2}{c}{ Rains } \\
\hline & P. difficilis & P. melanotis & P. difficilis & P. melanotis \\
\hline Adult males & 47 & 29 & 60 & 42 \\
Adult females & 17 & 17 & 27 & 39 \\
Reproductive males & 14 & 9 & 9 & 16 \\
$\begin{array}{l}\text { Reproductive } \\
\text { females }\end{array}$ & 13 & 7 & 5 & 14 \\
\hline
\end{tabular}


In overall, the number of captures of reproductive males was twice the captures of reproductive females in P. difficilis, and we also detected a decrease in captures of breeding individuals from the dry to the rainy season (Table 1). In contrast, the number of captures of breeding males and females was very similar in P. melanotis (16:14). That is, our results supported that the main reproductive period for $P$. difficilis occurred during the dry season, while the same was true during the rainy season for $P$. melanotis (Table 1 ).

In the dry season, Kernel's maps revealed a different use of space between males and females of $P$. difficilis (Figure1) with some overlaps in certain capture points, though we detected that males occurred on a broader area along the plot than females. On the contrary, males and females of $P$. melanotis show distribution overlaps in the capture points (Figure 1). In contrast, in the rainy season, we observed a high decrease in the dispersion of females of $P$. difficilis along the plot, while males of this species still expanded its dispersion along the plot (Figure 2), even though both sexes were captured almost in the same sampling stations. On the other hand, both males and females of $P$. melanotis expanded their distribution area within the plot during the rainy season, and we observed more overlaps between sexes of this species at the sampling stations (Figure 2).

\section{Mring}
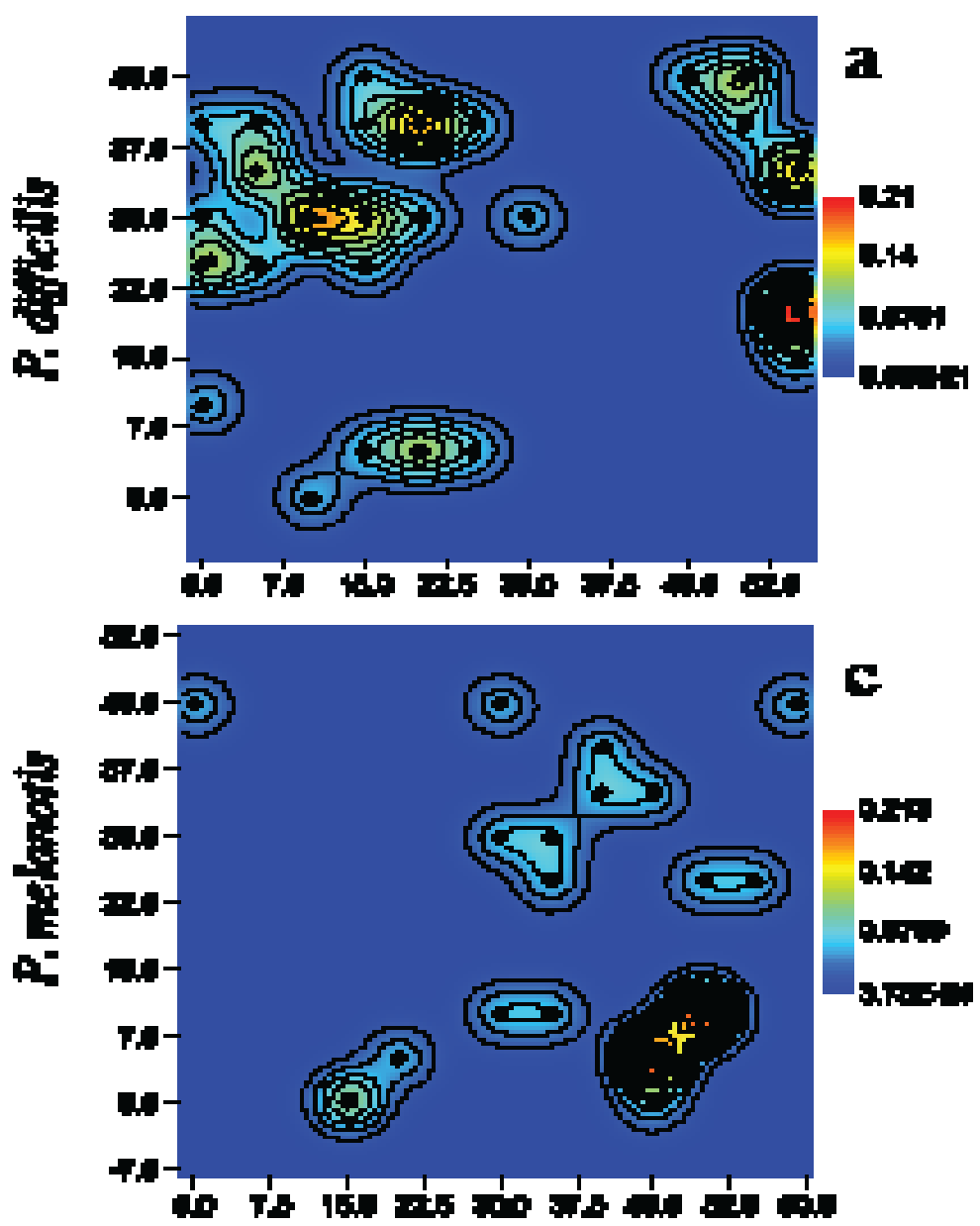

In both seasons, the Nearest Neighbor Analysis revealed that males and females of each species showed a significant clustered pattern within the plot with both specific and sex differences (Table 2). Therefore, during the dry season (Table 2), the mean distance was farther among females of $P$. difficilis, and males were more clustered; while males and females were at a similar mean distance in $P$. melanotis. In the rainy season (Table 2), females remained more distant from each other than males, though the mean distance between individuals decreased in $P$. difficilis, while mean distance increased in males of $P$. melanotis and females had a reduction in their occupied area.

In the dry season, Ripley's bivariate Kanalysis within species (Figure 3 ) revealed that males and females of $P$. difficilis were mainly positively associated at short distances with the major intensity of association at 2 and $6 \mathrm{~m}$. Similarly, although males and females of $P$. melanotis exhibited higher association than $P$. difficilis, the major intensity of such association also occurred at 6 and $12 \mathrm{~m}$ (Figure 3). In the rainy season, males and females of $P$. difficilis were randomly dispersed in almost all the distances showing the major positive association at 2 and $6 \mathrm{~m}$, and little peaks at distances 8 and $12 \mathrm{~m}$. In contrast, males and females of $P$. melanotis showed a negative association at $5 \mathrm{~m}$, followed by high positive associations at all analyzed distances (Figure 3).

\section{Ferrals:}

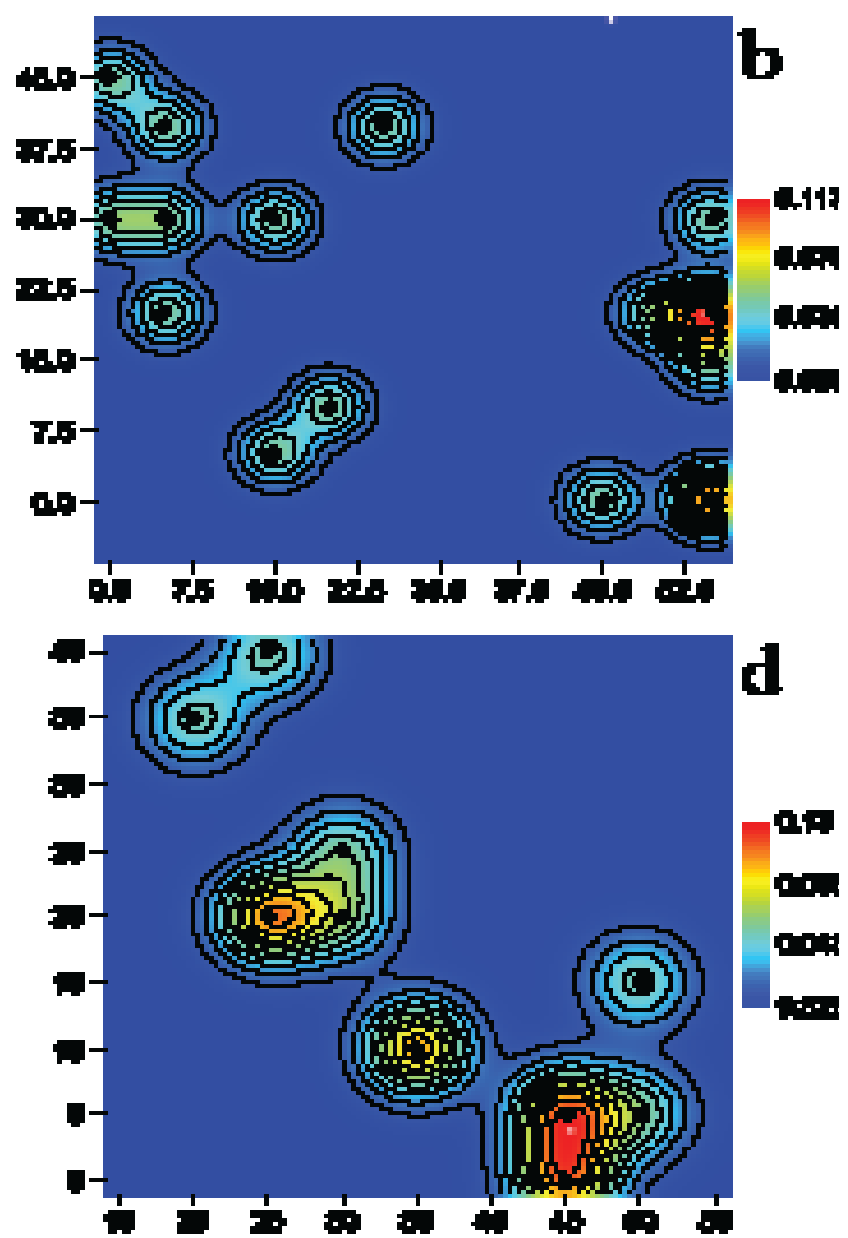

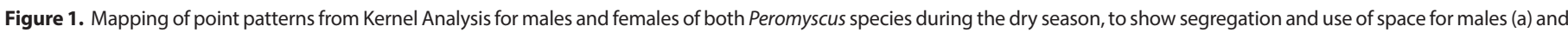
females (b) of $P$. difficilis; males (c) and females (d) of $P$. melanotis. Dots indicate actual capture points; red colors depicts higher density. Scales in both axes are in meters. 

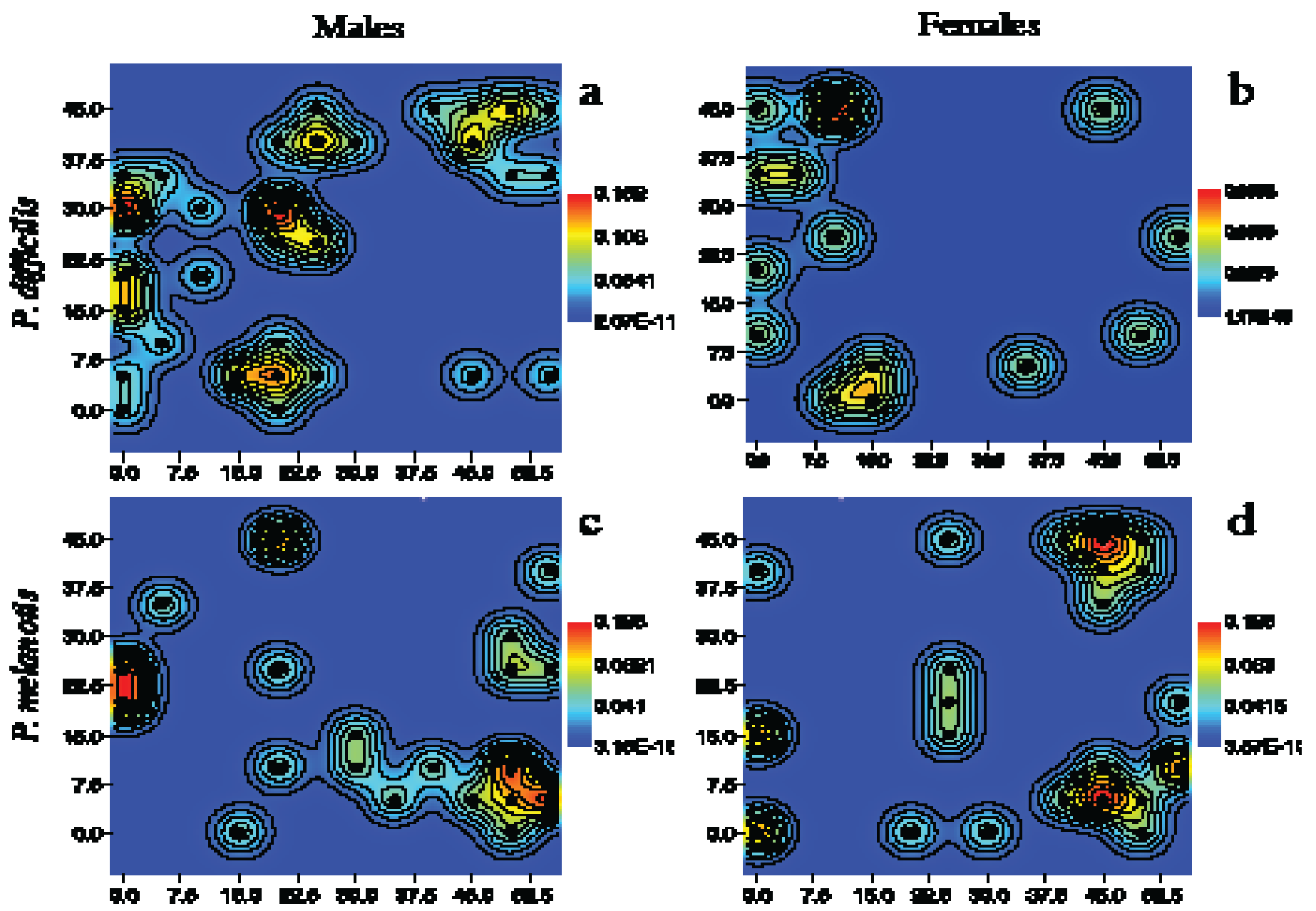

Figure 2. Mapping of point patterns from Kernel Analysis for males and females of both Peromyscus species, during the rainy season, to show segregation and use of space for males (a) and females (b) of P. difficilis; males (c) and females (d) of P. melanotis. Dots, red colors, and axes scales as in figure 1.

In the dry season, Ripley's bivariate $\mathrm{K}$ analysis between sexes of the species (Figure 4) revealed a clear negative association at all distances between males of $P$. difficilis vs. males of $P$. melanotis (Figure 4). Nevertheless, the females of $P$. difficilis $v$ s. females of $P$. melanotis exhibited a random pattern of distribution. Therefore, we cannot reject the null hypothesis (Figure 4). In contrast, in the rainy season, males of $P$. difficilis vs. males $P$. melanotis revealed a positive association in different distances and repulsion at $5 \mathrm{~m}$. While females of $P$. difficilis $v$ s. females of $P$. melanotis also showed an association at different distances (Figure 4).

\section{Discussion}

As expected from a relatively common pattern in studies conducted with Peromyscus species, we captured more males than females in both species. In general, females have smaller daily home ranges (DHRs) and lowest movements above ground than males, especially during the dry seasons (Trivers 1972; Gittleman and Thompson 1988). Thus, differences in captures between the sexes and smaller female's DHRs in both species of Peromyscus, could be a consequence of reproductive roles, since females need to allocate more energy than males into mating, and especially

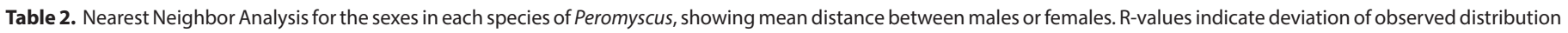
from random as follows: Clustered points $=R<1$; Poisson patterns $=R \sim 1$; overdispersed points $=R>1$.

\begin{tabular}{|c|c|c|c|c|c|c|c|c|}
\hline & \multicolumn{4}{|c|}{ Dry season } & \multicolumn{4}{|c|}{ Rain season } \\
\hline & \multicolumn{2}{|c|}{ P. difficilis } & \multicolumn{2}{|c|}{ P. melanotis } & \multicolumn{2}{|c|}{ P. difficilis } & \multicolumn{2}{|c|}{ P. melanotis } \\
\hline & Males & Females & Males & Females & Males & Females & Males & Females \\
\hline Points & 47 & 17 & 29 & 17 & 60 & 27 & 42 & 39 \\
\hline Mean distance & 2.04 & 4.43 & 2.72 & 2.59 & 1.33 & 2.66 & 3.06 & 1.86 \\
\hline$R$ & 0.56 & 0.73 & 0.59 & 0.57 & 0.41 & 0.55 & 0.70 & 0.43 \\
\hline Pvalue & $1.6763 \times 10^{-8}$ & 0.036409 & $2.4924 \times 10^{-5}$ & 0.00074115 & $4.4812 \times 10^{-18}$ & $1.094 \times 10^{-5}$ & 0.001336 & $9.2124 \times 10^{-11}$ \\
\hline Point pattern & clustering & clustering & clustering & clustering & clustering & clustering & clustering & clustering \\
\hline
\end{tabular}



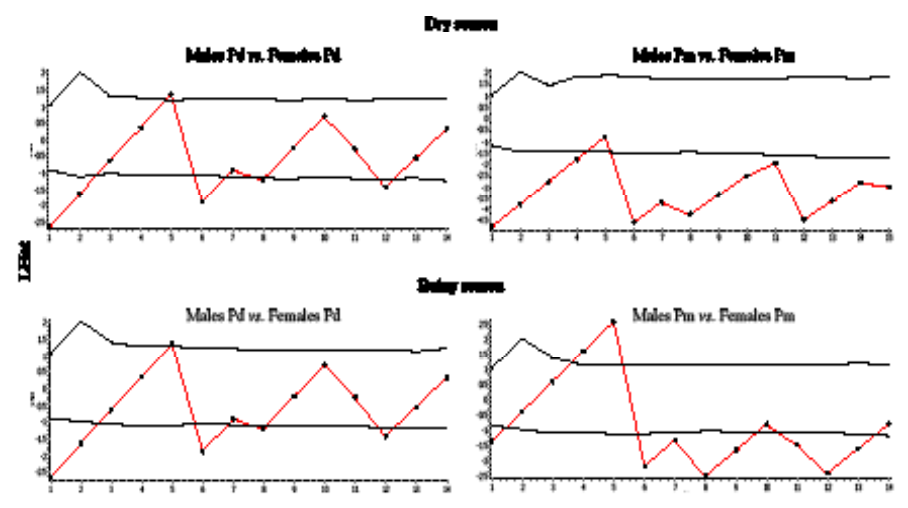

and

Figure 3. Shifts in interaction patterns (attraction-repulsion) between the sexes of each Peromyscus in dry and wet seasons, according to Ripley's bivariate K Analysis. The solid blue line represents Ripley's K bivariate pattern, while red dashed lines depict the area of a $95 \%$ confidence interval $(\mathrm{Cl})$. Thus, if blue lines fell within the $95 \% \mathrm{Cl}$ area, the null hypothesis of random interaction cannot be rejected; while if blue lines fell either below or above this area, the sexes were either attracted or repulsed, respectively. In $P$. difficilis $(\mathrm{Pd})$, there was a high positive association between both sexes at all analyzed distances during the dry season, while both sexes had random segregation along the plot at rains, but still with attraction patterns at $1-3,6,8$, and $12 \mathrm{~m}$. P. melanotis ( $\mathrm{Pm})$ had a more stable pattern of positive association between the sexes in both pluvial seasons: the sexes were highly attracted to each other in all analyzed distances during the dry season, and there was only a negative association (repulsion) at $5 \mathrm{~m}$ of distance between them during the rainy season, remaining associated in all other distances.

into gestation, delivery, nursing, and raising of pups, which would occur at the expense of energy invested in displacements (Gittleman and Thompson 1988). Availability of food resources has been considered as one of the most critical factors influencing the use of space in mammals (Dimitri et al. 2009; Adler 2011; Adrian and Sachser 2011; Maher and Burger 2011). Therefore, in order to maximize their fitness, the distribution of females could be profoundly influenced by the distribution of food resources (Adler 2011), mainly if food resources are scattered and with lower renewal rates, while the males are distributed according to the distribution of the females (Ostfeld et al. 1985). Here, we found that males and females of both species showed a clustered pattern of dispersion. However, males of $P$. difficilis displayed a more segregated pattern of distribution in the reproductive season (dry season), when they became highly associated with the females.

In contrast, males of $P$. melanotis showed a similar use of space as females along the plot, or at least they were captured in nearby stations in both seasons; indeed, such positive association pattern between sexes increased throughout the reproductive season (rainy season) in this species. Therefore, intraspecific temporal changes in mean distances between the sexes, as well as temporal patterns of association, showed us that the distribution of females could influence the distribution of the males. Moreover, when we compare the positive association or repulsion of the sexes between species (i. e., males of $P$. difficilis $v$ s. males of $P$. melanotis and females of $P$. difficilis vs. females of $P$. melanotis), we observed that in the dry season, the males of both species were associated negatively, while the females did not show an association. In contrast, in the rainy season, males and females showed a positive association at different distances analyzed. This support that the distribution of males

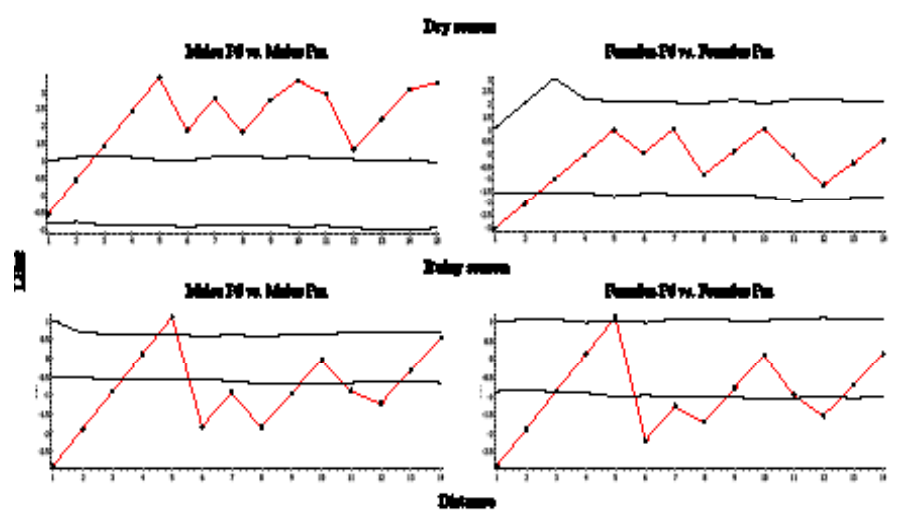

Figure 4. Shifts in interaction patterns (attraction-repulsion) between males of $P$. difficilis $(\mathrm{Pd})$ vs. males of $P$. melanotis $(\mathrm{Pm})$ and between females of $P$. difficilis $(\mathrm{Pd})$ vs. females of $P$. melanotis $(\mathrm{Pm})$ in dry and wet seasons, according to Ripley's bivariate $\mathrm{K}$ Analysis. The solid red line represents Ripley's K bivariate pattern, while dark dashed lines depict the area of a $95 \%$ confidence interval $(\mathrm{Cl})$. Thus, if red lines fell within the $95 \% \mathrm{Cl}$ area, the null hypothesis of random interaction cannot be rejected; while if red lines fell either below or above this area, the sexes were either attracted or repulsed, respectively. In the dry season, males of both species are negatively associated at all distances, while females of both species had random segregation along the plot. In the rainy season, males of both sexes were positively associated at different distances with a little peak of repulsion at $5 \mathrm{~m}$. This last pattern also was observed for females of both species.

is profoundly influenced by the use of space of the females. We also believe that the repulsion pattern in the dry season between males of both species occurs due to resources availability are more scarce during this season. Therefore, the competition for the resources is more intense.

Furthermore, the primary breeding season of $P$. difficilis occurs in the dry season and thus, is probably that territoriality behavior can occur in the males that are searching for mating. Conversely, the intensity of such repulsion decreased substantially during the rainy season; indeed, at some analyzed distances, the two deer mice showed an association pattern. Holding our results that the increase of resources during the rainy season can allow that the species can share the habitat and coexist (De-la-Cruz et al. 2018). Thus, our results indicate that in these two syntopic Peromyscus, both microhabitat use and spatial organization are seasonally variable depending on the breeding season of both small mammals (Pianka 1973; Schoener 1974; Brown and Zeng 1989; Cramer and Willig 2002; De-la-Cruz et al. 2018).

Sexual differences in use of space by each species could be due to different habitat requirements by females and males during the breeding season (Morris 1984). Females must select safe nesting sites for their young (e. g., against predation), and must spend considerable time at or near those sites, nurturing young. Thus, small female home ranges may be more a constraint of their reproductive role than an adaptation for enabling foraging at resourcerich habitats. Although males also require nest sites, their parental responsibilities give them greater freedom and opportunity to select microhabitats by resource levels or mate availability (Morris 1984).

We confirmed that the reproductive season of $P$. difficilis occurs mainly during the dry season, while that for $P$. melanotis arises in the rainy season. In consensus, Salame-Méndez et al. (2003a, b; 2004a, b) documented highest intrago- 
nadal contents of testosterone and other sex steroids in females of $P$. melanotis during the rainy season, while Castro-Campillo et al. (2008), found that $P$. difficilis had its reproductive optimum during the dry season at the PNDL. The excluding and shifted breeding patterns in this two syntopic Peromyscus are followed by population increases (Castro-Campillo et al. (2008)), thus allowing their coexistence in their mixed forest at this midlatitude study area.

In summary, we conclude that in our, temperate forest: 1) use of space by P. difficilis and P. melanotis, is influenced by both sex of the individuals and by reproductive season, and that this pattern varies, according to shifts on ecological conditions that promote variation and availability of resources during dry and wet seasons; 2 ) there are interspecific differences in the use of space with conspicuous intraspecific differences in females and males of $P$. difficilis ( $e$. $g$. males are more territorial, and both sexes only become more clustered during the breeding season), while both sexes behave very similar in $P$. melanotis, indicating a much more gregarious behavior; and 3 ) there is a clear differentiation in the reproductive seasons of both species that could be related to resources available, such as shelters and food (see De-la-Cruz et al. 2018).

\section{Acknowledgments}

We thank J. L. Patiño Ortega and C. Peralta Juárez for their fieldwork assistance and all friendly logistic support. The staff at UAM-I mammal scientific collection kindly provided all the facilities for specimen curation and housing. We also thank the two anonymous reviewers for their valuable comments. Authorities in charge of DLNP (CORENA, SEMARNAT), as well as the forest rangers and administration staff at the National Park, provided us with information, security, and logistics to complete our studies. Collecting permit, SEMARNAT-08-049-B, was issued by Dirección General de Vida Silvestre, SGPA-09712/13, SEMARNAT, to Alondra Castro-Campillo (ACC). This paper contains partial information from the thesis for partial fulfillment of Master in Biology (DCBS, UAM-I) by IMDA; IMDA received financial support through a fellowship (283799, CVU 479479) from the Consejo Nacional de Ciencia y Tecnología (CONACyT). This study was supported by annual grants to AACC (143.***. 46 IB-DCBS-UAMI, 2013-2017).

\section{Literature cited}

AdLER, G. H. 2011. Spacing patterns and social mating systems of echimyid rodents. Journal of Mammalogy 92:31-38.

Arnovist, G., AND L. Rowe. 2005. Sexual conflict. Princeton University Press, Princeton. U. S. A.

AlLeN, J. A. 1891. Notes on new or little-known North American mammals, based on recent additions to the Collection of Mammals in the American Museum of Natural History. Bulletin of the American Museum of Natural History 3:263-310.

Allen, J. A., AND F. Chapman. 1897. On a collection of mammals from Jalapa and Las Vigas, State of Veracruz, Mexico. American Museum of Natural History 9:197-268.
AdrIAN, O., AND N. SaCHSER. 2011. Diversity of social and mating systems in cavies: a review. Journal of Mammalogy 92:39-53. Álvarez-Castañeda, S.T. 2005. Peromyscus melanotis. Mammalian Species 764:1-4.

Blondel, D. V., J. Pino., And S. M. Phelps. 2009. Space use and social structure of long-tailed singing mice (Scotinomys xerampelinus). Journal of Mammalogy 90:715-723.

BRown, J., AND Z. ZENG. 1989. Comparative population ecology of eleven species of rodents in the Chihuahuan desert. Ecology 70:1507-1525.

Bowers, M. A., AND H. D. Smith. 1979. Differential habitat utilization by sexes of the Deermouse, Permomyscus maniculatus. Ecology 60:869-875.

Brouard, M. J., T. Coulson., C. Newman., D. W. Macdonald., C. D. BUESCHING., AND A. W ReED. 2015. Analysis on population level reveals trappability of wild rodents is determined by Previous trap occupant. PloS One. https://doi.org/10.1371/journal. pone.0145006

Castro-Campilo, A., A. Salame-Méndez., A. Vergara-Huerta., A. Castlllo., and J. Ramírez-Pulido. 2008. Fluctuaciones de micromamíferos terrestres en bosques templados aledaños a la Ciudad de México. Pp 391-410 in Avances en el Estudio de los Mamíferos de México (Espinoza, L. C., and J. Ortega, eds). Publicaciones especiales. Vol. II, Asociación Mexicana de Mastozoología, A. C. Ciudad de México, México.

Carleton, M. D. 1989. Systematics and evolution. Pp. 7-141 in Advances in the Study of Peromyscus (Rodentia) (Kirkland, G. L., and Jr. J. N. Layne, eds). Texas Tech University Press. Lubbock, EE.UU.

CHESSON, P. 2000. Mechanisms of maintenance of species diversity. Annual Review of Ecology and Systematics 31:343-366.

ClaRK, P., AND F. Evans. 1954. Distance to nearest neighbor as a measure of spatial relationships in populations. Ecology 35:445-453.

ClutTon-BRock, T. 1989. Review lecture: mammalian mating systems. Proceedings of the Royal Society of London. Series B, Biological Sciences 236:339-372.

Clutton-Brock, T. H. 1991. The Evolution of Parental Care. Princeton University Press. Princeton, U. S. A.

Cramer, M., AND M. Willig. 2002. Habitat heterogeneity, habitat associations, and rodent species diversity in a sand: shinneryoak landscape. Journal of Mammalogy 83:743-753.

CONANP. 2006. Programa de Conservación y Manejo Parque Nacional Desierto de los Leones. Dirección General de Manejo para la Conservación, Comisión Nacional de Áreas Naturales Protegidas, Secretaria de Medio Ambiente del Gobierno del Distrito Federal, Secretaria del Medio Ambiente y Recursos Naturales. http://www.sma.df.gob.mx/

Dimitri, V., J. P. Blondel, and M. P. Steven. 2009. Space use and social structure of Long-Tailed Singing Mice (Scotinomys xerampelinus). Journal of Mammalogy, 90:715-723.

DALE, M. R. T. 1999. Spatial pattern analysis in plant ecology. Cambridge University Press. Cambridge, United Kindom.

Debra, M., J. ShIER, AND A. Randall. 1994. Spacing as a predictor of social organization in kangaroo rats (Dipodomys heermanni arenae). Journal of Mammalogy 85:1002-1008.

De-la-Cruz, I. M., A. Castro-Campillo, A. Zavala-Hurtado, A. SalameMéndez, and J. Ramírez-Pulido. 2018. Assessing the Relation between the spatiotemporal microhabitat heterogeneity 
and the dispersion patterns of two syntopic small mammals in a midlatitude temperate forest. bioRxiv 278390; doi: https://doi.org/10.1101/278390.

Fernández, J. A., F. Garcia-Campuzano, and M. S. Hafner. 2010. Peromyscus difficilis (Rodentia: Cricetidae). Mammalian Species 42:220-229.

Gaulin, S. J. C., and R. W. Fitzgerald. 1988. Home range size as a predictor of mating system in Microtus. Journal of Mammalogy 69:311-319.

GitTleman, J. L., AND S. D. Thompson. 1988. Energy allocation in mammalian reproduction. American Zoologist 28:863-875.

Heske, E. J., AND R. S. Ostfeld. 1990. Sexual dimorphism in size, relative size of testes, and mating systems in North American voles. Journal of Mammalogy 71:510-519.

Hammer, Ø., D. A. T. Harper, and P. D. Ryan. 2001. PAST: PAleontologicalSTatistics software package for education and data analysis. Palaeontologia Electronica 4:1-9.

Kamler, J., AND P. GIPSON. 2003. Space and habitat use by male and female raccoons, Procyon lotor, in Kansas. Canadian Field Naturalist 117:218-223.

MAHeR, C. R., AND J. R. BURGer. 2011. Intraspecific variation in space use, group size, and mating systems of caviomorph rodents. Journal of Mammalogy 92:54-64.

MorRIS, D. W. 1984. Sexual differences in habitat use by small mammals: evolutionary strategy or reproductive constraint? Oecologia 65:51-57.

MorRIS, D. W., AND T. J. MacEACHERn. 2010. Active densitydependent habitat selection in a controlled population of small mammals. Ecology 91:3131-3137.

OstFeld, R., W. LIdickER, AND E. HeSkE. 1985. The relationship between habitat heterogeneity, space use, and demography in a population of California Voles. Oikos 45:433-442.

Parker, G. A. 1979. Sexual selection and sexual conflict. Pp. 123-166 in Sexual Selection and Reproductive Competition in Insects (Blum M. S., and N. A. Blum., eds.). Academic Press. New York, USA.

PIANKA, E. R. 1973. The Structure of lizard communities. Annual Review of Ecology and Systematics 4:53-74.

Ramírez-Pulido, J., I. Lira, S. Gaona, Z. C Müdespacher, and A. CASTRO. 1989. Manejo y Mantenimiento de Colecciones Mastozoológicas. Universidad Autónoma Metropolitana. Ciudad de México, México.

RIPLEY, B. D. 1977. Modelling spatial patterns. Journal of the Royal Statistical Society, Series B 39:172-212.

RosenberG, M. S., AND C. D. Anderson. 2011. PASSaGE: pattern analysis, spatial statistics and geographic exegesis. Version 2. Methods in Ecology and Evolution 2:229-232.

SCHOENER, T. W. 1974. Resource partitioning in ecological communities. Science 185:27-39.

Salame-Méndez, A., J. Herrera-Muñoz, A. Castro-Campillo, and J. Ramírez-Pulido. 2003a. Valoración de esteroides sexuales en testículos de ratones juveniles de Peromyscus melanotis (Rodentia: Muridae). Revista de la Sociedad Mexicana de Historia Natural (3a época) l:83-90.

Salame-Méndez, A., R. M. Vigueras-Villaseñor, J. Herrera-Muñoz, e. Mendieta-Márquez, I. H. Salgado-Ugarte, A. Castro-Campillo, and J. Ramírez-Pulido. 2003b. Inmunolocalización y contenido de esteroides sexuales en ovarios de hembras de Peromyscus melanotis Allen y Chapman, 1897 (Rodentia: Muridae) durante la primera mitad de la preñez. Acta Zoológica Mexicana (nueva serie) 88:43-57.

Salame-Méndez, A., R. M. Vigueras-Villaseñor, L. Altamirano-León, J. Herrera Muñoz, and A. Castro-Campillo. 2004a. Análisis histológico del epitelio seminífero y del contenido de testosterona en testículos de Peromyscus difficilis (Rodentia: Muridae) de diferentes edades. Pp. 149-160 in Homenaje a la Trayectoria Mastozoológica de José Ramírez Pulido (Castro-Campillo, A., y J. Ortega, eds). Universidad Autónoma Metropolitana, Unidad Iztapalapa. Ciudad de México, México. Salame-Méndez, A., A. Castro-Campillo, E. Mendieta-Márquez, I. H Salgado-Ugarte, J. Herrera-Muñoz, and J. Ramírez-Pulido. 2004b. Evaluación estacional de la producción de esteroides sexuales en testículos del ratón de orejas oscuras (Peromyscus melanotis Allen y Chapman, 1897) de diferentes clases de edad. Acta Zoológica Mexicana (n. s.) 20:103-114.

TRIVERS, R. L. 1972. Parental investment and sexual selection. pp.136-179 in Sexual selection and the descent of man (Campbell, B., ed). Aldine. Chicago, USA.

UPTON, G. J. G., AND B. FInGLeTON. 1985. Spatial data analysis by example. Vol. 1: Point pattern and Quantitative Data. Wiley. Chichester, United Kindom.

VÁzquez, J., AND S. T. Álvarez-Castañeda. 2011. Spatial relationships between burrows of an insular population of Dipodomys merriami. Mammalian Biology 76:577-582.

Zavaleta, E. S., M. R. Shaw, N. R. Chiariello, H. A. Mooney, and C. B. FIELD. 2003. Additive effects of simulated climate changes, elevated $\mathrm{CO} 2$, and Nitrogen deposition on grassland diversity. Proceedings of the National Academy of Science 100:7650-7654.

Zavala-Hurtado J. A., P. L. Valverde, M. C. Herrera-Fuentes, and A. DIÁZ-SolIs. 2000. Influence of leaf-cutting ants (Atta mexicana) on performance and dispersion patterns of perennial desert shrubs in an inter-tropical region of Central Mexico. Journal of Arid Environments 46: 93-102.

Associated editor: Pablo Teta

Submitted: Agosto 28, 2018; Reviewed: Octuber 10, 2018;

Accepted:Octuber 30, 2018; Published on line: November 15, 2018. 